\title{
Consensus State of The Hindu Community in Bali
}

\author{
I Putu Windu Mertha Sujana ${ }^{1}$, Sukadi $^{1}$, Si Ngurah Ardhya ${ }^{1}$, I Made Riyan Cahyadi ${ }^{1}$, Ni Made \\ Widya Sari ${ }^{1}$
}

\{windu.mertha@undiksha.ac.id, sukadi.sukadi@undiksha.ac.id,ngurah.ardhya@undiksha.ac.id, riyan.cahyadi@undiksha.ac.id, widya.sari.2@undiksha.ac.id\}

${ }^{1}$ Universitas Pendidikan Ganesha

\begin{abstract}
The aim of this research is to find out the consensus of the state which is the foundation of Hindu's in Bali and the relationship between the consensus of the state and the values of Hindu spiritual culture in order to realize a harmonious, peaceful, and democratic state life. The method used is an ethnographic method with a qualitative approach. The subjects in this study were civic education practitioners, Hindu religious activist, and cultural practitioners. Data collection technique is using interview techniques semistructured interviews and observation techniques of complete participation. The data analysis technique used in this study is a data analysis technique which consists of three flow of activities that occur simultaneously, namely data reduction, data presentation, conclusion verification. The results of this study are the state consensus that forms the basis for Hindus in Bali, namely Pancasila, the 1945 Constitution of the Republic of Indonesia, Bhineka Tunggal Ika, and NKRI. The state consensus has a close relationship with the values of Hindu spiritual culture in the context of realizing a harmonious, peaceful and democratic state life. The first consensus is Pancasila which is likened to the roof that builds the Indonesian nation, the second consensus is the 1945 Constitution of the Republic of Indonesia as the constitutional basis, the third consensus is the Bhineka Tunggal Ika which functions as the spirit of development of the Indonesian nation, and the fourth consensus NKRI which functions as a fortress of protection, in strengthening the identity of the Indonesian nation.
\end{abstract}

Keywords: State Consensus, Hindu's in Bali, Citizens

\section{Introduction}

A harmonious, peaceful and democratic life is a dream for every citizen, including Indonesian citizens. Indonesia as a sovereign country has several guidelines that animate every line of national and state life in the context of realizing a harmonious, peaceful, and democratic life. The Hindu community in Bali in their position as Indonesian citizens and part of the Indonesian nation must refer to the basis and constitution in every activity carried out, both aspects of karma marga and jnana marga ( Hartaka and Suadnyana, 2018). Hindus must have a nationalist spirit in order to actualize these values, implicitly or explicitly. If everyone is able to carry out their respective duties and obligations, there will be harmony in society, because everyone will act 
according to their profession, talents and work which are their life obligations. We can find various professions in society and the Vedic scriptures distinguish between clergy and scholars, politicians, businessmen, and those who only use their energy known as varna, which means the choice of profession according to talent, ability and appropriate duties or responsibilities. heart choice. If examined further, the basic concepts of nationhood and state expressed by human beings actually originate from religious teachings that view humans as His creations, originating from the sacred and in the teachings of Hinduism, incarnating into this world is to eradicate bad karma by do as much good as possible, because materially the goal of human life is to prosper in this world. But spiritually it is attaining liberation and reuniting with it .

The preamble to the 1945 Constitution contains the national objectives of the development of the Indonesian nation, namely to protect the entire Indonesian nation and the entire homeland of Indonesia and to promote general welfare, educate the nation's life and participate in carrying out world order based on independence, eternal peace and social justice (Kirana, 2012: 3). National development is essentially the development of Indonesia as a whole and builds the entire Indonesian people with the aim of realizing the ideals of a nation's struggle for independence, unity, and people's sovereignty in an atmosphere of national life that is safe, peaceful, orderly and independent in an environment of world peace that is free and friendly to maintain national unity and integrity (Astawa, 2010: 121).

Hindus who are Indonesian citizens must be able to analyze a national and state problem by looking at contemporary phenomena. A person who believes in Hindu teachings must adhere to the values of Hindu teachings by applying them to everyday life. By becoming a citizen subject to the laws of the country itself. This is a yadnya that aims to achieve a goal. In Hinduism it is known as Moksartham Jagathita ya ca Iti Dharma (Pranata, 2009:12). This study aims to determine the state consensus that forms the basis for Hindus in Bali and the relationship between state consensus and Hindu spiritual cultural values in order to realize a harmonious, peaceful, and democratic state life.

\section{Methods}

This study uses a qualitative research approach with ethnographic methods. The use of this educational ethnographic method considering that in this study the focus is on describing and providing a detailed explanation of spiritual cultural phenomena that can be reconstructed according to the perspective of research participants naturally. The phenomenon of spiritual culture in question is related to knowledge, values, beliefs, norms, traditions or habits, symbols, language, and daily life practices used in policy development and program implementation. Education Citizenship air base in the Hindu spiritual culture of the people of Bali with studies without ignoring critical and interpretive elements of empirical study. The subjects in this study were civic education practitioners, Hindu religious practitioners, and cultural practitioners. Data collection technique is using interview techniques semi-structured ( semistructured interviews ) and observation techniques of participation Full ( complete participation ). The data analysis technique used in this study is a data analysis technique which consists of three flow of activities that occur simultaneously, namely data reduction, data presentation, conclusion drawing/verification. 


\section{Results and Discussion}

Hindus in their position as Indonesian citizens need to understand and practice the four state consensus in their daily lives. The MPR RI (2020) describes the state consensus as four pillars of nationality that must be implemented by every Indonesian citizen, including Hindus in their daily lives, such as: the first consensus, namely Pancasila which is likened to the roof that builds the Indonesian nation; the second consensus is the 1945 Constitution of the Republic of Indonesia as the constitutional basis; the third consensus is the motto Bhineka Tunggal Ika which serves as the spirit of development of the Indonesian nation; and the fourth consensus is that the Unitary State of the Republic of Indonesia functions as a fortress of protection in strengthening the identity of the Indonesian nation. Citizenship Practitioners view that citizens must have good personalities and intelligent minds, this is because in the life of our country we will be faced with various events and problems that must be solved together in order to achieve a harmonious, peaceful, and democratic life. Life harmonious, peaceful, and democratic is the dream and goal of the Indonesian state, therefore the state expects every citizen of Indonesia to always obey and adhere to four k onsensus the state. The following will describe the four consensus states in the Hindu perspective which are obeyed and implemented by Hindus in Bali.

\section{Pancasila as the ideology of Hindu's}

The guidelines are used as f ilsafat life for Hindus dal am daily lives, on their families, communities, and countries a da was guided by the values of Pancasila. The values of Pancasila are explored and are the crystallization of the cultural values of the Indonesian nation. The value of Hindu Spiritual culture is one of the values that is in harmony with the values of Pancasila, it needs to be implemented. Cultural practitioners are of the view that the values of Hindu spiritual culture that are in line with the values of Pancasila as a philosophy of life need to be implemented in order to strengthen the spirit of the nation's struggle, especially the younger generation. Meaning t erkandung the fighting spirit is a da was to improve the quality of human resources of Indonesian young generation. Hindus are expected to participate in efforts to improve the human resources of Indonesia's young generation.

The younger generation or students must have an attitude that reflects the values of Pancasila in their daily lives. Practitioners of Hinduism are of the view that the values of Pancasila which are in harmony with Hindu values can be described as follows. The first precept (Belief in One Supreme God), six religions recognized by the state at the core of their teachings recognize the existence of God Almighty as the center of human life. Hinduism has a monotheistic view that recognizes that there is only one god. This Hindu concept is evidenced from the Regveda Mandala 1 Sukta 164, mantra 46 which states "Ekam sat wiprah bahuda wa danti, agnim yaman matariswanam", meaning that there is only one god, but the Rishis call him Agni, Yama, and Matariswanam. The concept of monotheism and acknowledging the existence of God by Hinduism, it is only natural that Hindus practice the values of the first precepts of Pancasila in their lives. This first precept is used as the basis when Hindus carry out religious dharma and state dharma in their daily activities. Some of the behaviors of the younger generation in their capacity as students who implement this first precept are diligently praying according to their religion and beliefs, respecting other friends who are carrying out their worship, and never contradicting the religious teachings we profess with different friends' religions because it can cause conflict. . 
The second precept ( Just and Civilized Humanity Precept ), has the meaning that we as Indonesian citizens, especially Hindus, should uphold human values, often carry out social activities in society, and hold fast to truth and justice. Hindu religious teachings that are in line with these precepts can be seen in Yayur Veda XI.6 which means that we are obliged to always do good to our fellow human beings, as we want them to do to us, and treat them as our brothers. Some of the behavior of the younger generation in their capacity as students in implementing this second precept, for example, when students are involved in campus organizational activities, should treat friends according to their dignity and worth, among students recognizing that they have the same degrees and have equal rights and obligations as human beings, and some Organizational work programs that students participate in are directed to carry out humanitarian activities.

The third precept (Unity of Indonesia), Hindus are required to always prioritize the principle of unity and integrity in the life of the nation and state, and prioritize the interests of the nation above the interests of individuals and groups. This indicates that Hindus can transform into figures who are able and willing to sacrifice for the interests of the nation and state based on a sense of nationalism. The values of Hinduism that are in line with this third precept can be seen in Yayur Veda IX.23 which means that we may always be vigilant in guarding and protecting the nation and country we love. In addition, the Atharwa Veda XII.1.2 requires us to be able to sacrifice our lives for the glory of the nation and country we love. Some of the attitudes that students must have are cultivating a sense of love for the homeland, being proud to be the younger generation of Indonesia, and upholding the value of unity based on Bhinneka Tunggal Ika every day .

The fourth precept, (Democracy Led by Wisdom of Wisdom in Deliberation and Representatives), Hindus are required to uphold the principles of democracy in their daily actions. Sila is also stressed that each person has rights and duties and equal so that no individual will be allowed to impose to the other. When Hindus want to take a decision with the need to prioritize doing deliberation ( sangkep or Paruman) in order to produce a consensus decision. We can see the teachings of Hinduism in line with this fourth precept in Reg Veda X.191.3 which means that we are obliged to gather together and think together in order to achieve the goal of living together and happiness. The attitude that must be possessed by students in line with these precepts is that when carrying out student organization meetings, it should be preceded by deliberation and accept the results of the deliberation in good faith and responsibility.

The fifth precept (Social Justice for All Indonesian People), Hindus are required to act well by upholding the attitude of kinship and mutual cooperation for the creation of social justice. Hindu religious teachings that are in line with these precepts as stated in the Isa Upanisad Sloka 1 which means we should accept what we need and what has been intended for us and never want something belonging to someone else. Manawa Dharmasastra IV.226 also obliges us not to get tired of making offerings and alms sincerely, because offerings and alms based on sincerity will lead them to be able to achieve moksa (the highest life goal of Hindus). Students' attitudes that are in line with these precepts are happy to give help to friends with the aim that friends can be independent in the future, students' property rights are not used extravagantly and are not used to extort friends, students like to work hard every day, and students always respect the work of his friends which is useful for mutual progress and welfare. 


\section{The 1945 Constitution of the Republic of Indonesia in instilling the attitude of defending the state of Hindus}

People of Hind $\mathrm{u}$ in his capacity as a citizen of Indonesia, of course all of his behavior adjusted to the state constitution that the Constitution of 1945. Liabilities NRI Hindus to defend his country was included in pasal 27 line 3 of the Constitution NRI 1945. The attitude and spirit of the civil defense in harmony with the teachings of Hinduism as stated in Sarasamuscaya 31, which states "Matangnyan pengpongan authorityta, mangken rare ta pwa kitancepataken agawe dharmasadhana; apan anitya iking hurip, syapa curry wruha emphasize the starch wih ". The point here is that we as the younger generation should use the abilities we have as well as possible and we are required to be able to carry out our obligations based on the teachings of dharma, because human life is not eternal and death can come at any time. The obligation to defend the state owned by Hindus is the implementation of the state dharma teachings of Hindus. Citizenship education practitioners holds if $\mathrm{k}$ ewajiban defending the country which is based on the Hindu dharma is not merely the means to fight physically but using non-physical ways, for example by using the potential of the young generation to be used in the national interest.

$\mathrm{U}$ mat Hindu must understand that the war faced by Indonesia today is a war proxy war and mental war that capitalizes on the intelligence of the citizens. The discourse of mental revolution echoed by the government is a sign that our nation is experiencing urgency. The flow of globalization and intelligence is the source. Globalization which has infected the Indonesian people very strongly coupled with the intelligence of citizens who are still weak has resulted in the urgency of the Indonesian state in this war. The only way to win this mental war is to improve the intelligence of the nation's young generation. Practitioners of Hinduism are of the view that Hindus have the teachings of Tri Kaya Parisudha which are seen as being able to improve and increase the intelligence of the younger generation. This teaching teaches us to always think, say, and act what is right and good. The thoughts of the younger generation who have been guided towards goodness, then their words will be good and will not nudge the diversity of the Indonesian nation or in other words if the minds of the younger generation are good it will produce good behavior too. Tri Kaya Parisudha which is used as the foundation of Hindus and harmonized with the teachings of Tri Hita Karana will bring harmony. These two concepts give us an idea that defending the country can be carried out in a simple way. Defending the country carried out by the younger generation is enough just to sharpen their minds to be more brilliant and wise. Right and good thoughts, words, and actions are also a manifestation of defending the country in order to establish harmony among citizens. We can take an example from the story of the Mahabharata, where the great and strong kingdom of Astina could be destroyed due to bad thoughts, causing bad words and actions as well, resulting in a civil war between the Pandavas and the Kauravas.

Defending the country does not look at its ethnicity, religion, and race, but rather how we consider other people as our brothers, in the Hindu concept known as Vasudaiva Kutumbhakam. The proverb also says "those who are not your brothers in the faith, are your brothers in humanity". We can see Hindu teachings that uphold love for the homeland and defend the country in Yayur Veda IX.23 which reads "Vayam rastre jagryama porohitah" means that we always guard and protect the nation and state. Other books as well as listed in the Atharvaveda XII.1.2 that reads "Vayam tubhyam balihrtab Syama" meaningful so that we can sacrifice our body and soul to the glory of the nation and state of Indonesia. 


\section{Bhineka Tunggal Ika as a motto that binds the lives of Hindu's}

Hindus in their daily lives are also based on the consensus of a third country, namely Bhineka Tunggal Ika. Cultural practitioners are of the view that the attitude of upholding good cultural tolerance has been shown by Indonesian citizens since the days of the kingdom. The cultural diversity in each region has united to form a living community together called the Indonesian nation. Kaelan (2012) is of the view that cultural unification will not eliminate diversity, which he calls Bhinneka Tunggal Ika. Practitioners of Hinduism are of the view that the state motto, Bhinneka Tunggal Ika, is actually taken from Kekawin Sutasoma Pupuh 139 stanza 5, written by Mpu Tantular, which reads "Rwaneka dhatu winuwus wara Buddha Wiswa, Bhinneki rakwa ring apan gets parwanosen, mangka ng Jinatwa singular, Bhinneka Tunggal Ika Tan Hana Dharma Mangrwa". Told in ancient times that Buddha and Shiva are two different substances, even if they differ will but we can not see the difference, because the real truth taught by the Buddha and Shiva it is singular, indeed they are different but essentially the same, because there is no truth ambiguous. Gunawijaya (2020) explained that Mpu Tantular lived during the era of the Majapahit kingdom and when this era was heavily influenced by the teachings of Shiva and Buddha. Suamba (2009) also added that the Sutasoma marriage was written from the point of view of Mahayana Buddhism.

We should realize that the Indonesian state which was built with the Pancasila ideology in the symbol of the Garuda Pancasila with the motto "Bhinneka Tunggal Ika" has taught us that the founders of the nation realized that the elements that built the Indonesian state were very diverse in terms of population and geography. Juridically, we can see that the use of Bhinneka Tunggal Ika as the motto of the Indonesian state is stated in pasal 36A of the 1945 Constitution of the Republic of Indonesia. The concept of Bhinneka Tunggal Ika has brought us to this day to become a great nation and is respected by other nations. Although we come from different ethnic and religious will, but we remain one as Indonesian. Suadnyana (2019) emphasizes all Hindus to reflect on the concept of Bhinneka Tunggal Ika and implement it by prioritizing the principle of nationalism in diversity.

The motto "Bhinneka Tunggal Ika" can be used as the formation of one's identity. In a person there is a conscience that can judge morally the actions he takes. Bhineka Tunggal Ika is used as a benchmark in the formation of identity with a conscience that oversees the behavior of the person. The formation of one's identity is expected to know and understand oneself with full awareness of doing to participate in building national identity. Referring to self-awareness, it is hoped that Hindus will be able to transmit it to the family environment, so that Hindus can be actively involved in realizing the development, defense, and preservation of their respective regional identities, finally being able to make their respective regional identities as national identities (Darmawan, 2020). The formation of national identity was marked by the Youth Pledge, in which all youth elements from various regions declared themselves to be Indonesians. The younger generation of the nation's successors, it is only natural that at this time they must understand the meaning of the Youth Pledge Pledge for the formation of their identity as the Indonesian nation.

\section{The Unitary State of the Republic of Indonesia is a symbol of Hindu nationalism}

The fourth state consensus that Hindus adhere to and implement is the Unitary State of the Republic of Indonesia. Practitioners of civic education are of the view that maintaining state sovereignty is a very difficult task, because Indonesia's territory stretches from Sabang to Merauke. The territory of Indonesia consists of 17,504 islands, with a land area of 1,922,570 
$\mathrm{Km}^{2}$ and a water area of $3,257,483 \mathrm{Km}^{2}$. Therefore, in an effort to maintain and defend the integrity and sovereignty Homeland can not be handed over to the military and police alone, will but also the duty of a citizen of Indonesia.

Homeland does not stand by itself or be awarded prizes by other countries, would be but the Homeland exist due to the struggle of our freedom fighters in an effort to gain independence. The fighters sacrificed their whole soul and body for the sake of Indonesian independence. Our task as the nation's young generation is to maintain the integrity of the Unitary State of the Republic of Indonesia. The integrity of the Unitary State of the Republic of Indonesia is shown through: 1) Indonesia as a whole and not divided country; 2) the creation of a harmonious relationship between the people and their government; 3) there is no war or rebellion among the people; 4) the creation of a safe and peaceful state and condition.

All Indonesian citizens, including Hindus, in order to have the awareness to maintain and defend the sovereignty and integrity of the Unitary State of the Republic of Indonesia need to be instilled in them an attitude of nationalism. Cultural practitioners argue that the principle of nationalism can be synergized with religious spirit which is called religious nationalism. Religious nationalism makes religion a value and a spirit in realizing a just and prosperous country. Therefore, it can be said that the state and religion have a symbiotic relationship of mutualism. Things that can threaten the integrity of the Unitary State of the Republic of Indonesia is when using the guise of religion as a politicization for the interests of the state elite. Practitioners of Hinduism declare Hindu religion in Yajurveda XXIII. 15 with the sound Svayam vajin tanvam kalpayasva svayam yajasva svayam jusasva, mahima te anyena na samnase has taught Hindus to always adhere to the teachings of dharma. Maintaining the integrity of the Unitary State of the Republic of Indonesia can be done when Hindus are able to implement the dharma of their religion and the dharma of their country. The obligations of Hindus in carrying out religious dharma and state dharma are carried out by prioritizing love and brotherhood, developing solidarity, improving the quality of human resources, upholding Hindu morality, maintaining harmonious relations based on the teachings of tri hita karana, distancing themselves from unlawful acts that result in harm other people or the state such as corruption, stealing and so on, as well as upholding the integrity of Hindus in the aim of strengthening national unity.

\section{Conclusion}

The state consensus that forms the basis for Hindus in Bali is Pancasila, the 1945 Constitution of the Republic of Indonesia, Bhineka Tunggal Ika, and the Unitary State of the Republic of Indonesia (NKRI). Consensus state that is well aligned with the values of the Hindu spiritual culture in order to realize the state of life that is harmonious, peaceful, and democratic. Consensus first namely Pancasila that depicted as a roof that building a nation of Indonesia, the consensus second is the Constitution NRI 1945 as the constitutional basis, the consensus third is the motto of Unity in Diversity which serves as the spirit of Indonesian nationbuilding, and consensus-four is the Homeland that serves as a bulwark of protection in strengthening the identity of Indonesia. 


\section{References}

[1] Astawa, Dewa Nyoman Wija. 2010. Pola Pikir Meningkatkan Wawasan Kebangsaa Mencegah Disintegrasi Bangsa. Paramita, Surabaya.Darmawan, I. P. A. (2020). Animisme dalam Pemujaan Barong Bulu Gagak di Bali. Genta Hredaya, 4(1)

[2] Gunawijaya, I.W.T.(2020). Konsep Teologi Hindu Dalam Geguritan Gunatama (Tattwa, Susila, dan Acara). Jñānasiddhânta: Jurnal Teologi Hindu, 2(1).

[3] Hartaka, I.M \& Suadnyana, I.B.P.E. (2018). Dharma Agama dan Dharma Negara di Era Kekinian. Jurnal Pariksa, 2 (1), hlm. 81-94

[4] Kaelan. (2012). Problem Epistemologi Empat Pilar Berbangsa dan Bernegara. Yogyakarta Paradigma.

[5] Kirana, D.C,dkk. (2012). UUD 45 dan Perubahannya. Jakarta: Niaga Swadaya

[6] MPR. (2020). Materi Sosialisasi Empat Pilar MPR RI. Jakarta: Sekretariat Jendral MPR RI.Pranata. 2009. Upacara Ritual Perkawinan Agama Hindu Kaharingan. Surabaya: Paramita

[7] Republik Indonesia. (2002). Undang-Undang Dasar Negara Republik Indonesia Tahun 1945 Amandemen Keempat. Jakarta: Majelis Permusyawaratan Rakyat.

[8] Suadnyana, IBPE. (2019). Ajaran Agama Hindu Dalam Geguritan Kunjarakarna. Genta Hredaya, $3(1)$.

[9] Suamba, IB.P. (2009). Siwa-Buddha di Indonesia Ajaran dan Perkembangannya. Denpasar: PT. Mabhakti 